\title{
IAMJ
}

INTERNATIONAL

AYURVEDIC

MEDICAL JOURNAL

Case Report

ISSN: 2320-5091

Impact Factor: 6.719

\section{AYURVEDA APPROACH IN THE MANAGEMENT OF ANTERIOR CRUCIATE LIGAMENT TEAR OF KNEE}

\section{Sreelatha $K^{1}$., George M.J'², Kishor $\mathbf{R}^{3}$}

${ }^{1}$ Second year P.G. scholar, Dept. of Shalyatantra, V.P.S.V A.V.C., Kottakkal, Kerala, India

${ }^{2}$ Professor and H.O.D., Dept. of Shalyatantra, V.P.S.V A.V.C., Kottakkal, Kerala, India

${ }^{3}$ Asst. professor., Dept. of Shalyatantra, V.P.S.V A.V.C., Kottakkal, Kerala, India

Corresponding Author: srilata.hari@gmail.com

\section{https://doi.org/10.46607/iamj2209062021}

(Published Online: June 2021)

Open Access

(C) International Ayurvedic Medical Journal, India 2021

Article Received: 13/05/2021 - Peer Reviewed: 02/06/2021 - Accepted for Publication: 04/06/2021

Check for updates

\section{ABSTRACT}

The knee is one of the largest and most complex joints in the body. The two cruciate ligaments in the knee, anterior and posterior, are often referred to as the 'crucial' ligaments, because of their importance in providing knee stability. Anterior cruciate ligament (ACL) injury is one of the most seen injury in sports and has a devastating influence on patients' activity levels and quality of life. Complete ACL rupture can induce other pathological knee conditions including knee instability, damage to menisci and the chondral surface, and osteoarthritis. Here a case report of a 28-year-old male who while playing football had a trauma to the right knee with a pop sound and acute pain at the time of incidence. He presented to the hospital with a knee which was swollen and tender. On MRI he was diagnosed with complete tear of ACL and grade II tear of lateral collateral ligament. A one-month Ayurveda treatment protocol was developed and followed for the patient. The patient was able to return to his daily activities without instability and also got relief from pain with noticeable improvement in the movement of knee joint.

Keywords: anterior cruciate ligament tear, knee joint, janu sandhi, bhagna 


\section{INTRODUCTION}

The knee is one of the primary weight bearing joints of the body. The price of its mobility is a tendency to instability. ${ }^{1}$ It is also one of the most commonly injured joints as it is easily subjected to external forces, because of its anatomic structure and also due to the functional demands laid upon it. ${ }^{2}$ The stability of knee joint is maintained by the ligaments, tendons and the associated muscles. Anterior cruciate ligament injuries account for between $25 \%$ to $50 \%$ of ligamentous knee injuries. ${ }^{3}$ ACL injury poses unique clinical problems because of its poor capacity to undergo biological healing due to the local intra-articular conditions. ${ }^{4}$ It is said that the anterior cruciate ligament rupture are "the beginning of the end of the knee". ${ }^{2}$ The common clinical findings after an ACL tear are restricted movements mainly extension, diffuse mild tenderness on knee. Usually the Lachman's test is positive and also is very reliable in ACL rupture. The anterior drawer test may also be positive in most of the cases of ACL tear but literature says that its specificity is very less. ${ }^{5}$ After a suspected ACL injury, an X-ray evaluation should always be done because radiographs may reveal an avulsion of the ligament from the tibia or a Segond fracture at the lateral margin of the tibial plateau. ${ }^{5}$ MRI should be preferred in conditions where the diagnosis cannot be confirmed. The prognosis of ACL tear also depends on the fact that grossly there are two types of knee. First one which is the ACL dependent knee with poor secondary stabilizers. The second knee in which there will be well functioning secondary stabilizers and thus such a knee may not be completely dependent on the ACL. It is seen that a knee may have a satisfactory functional outcome even with a deficient anterior cruciate ligament for a long time. Any further trauma which may occur to knee later may predispose symptoms. ${ }^{2}$ The decision whether the rupture should be managed conservatively or surgically depends a lot on the following factors- age, degree of instability, associated abnormalities, whether or not the patient intends to perform pivoting activities with the leg, occupation, social factors such as cost of treatment and the time, willing to undergo rehabilitation. ${ }^{5}$
ACL injuries usually occur in combination with other ligament or meniscal tears. The degree of the associated injuries also influences the outcome. The principles of rehabilitation process which is to be followed in conservative management are reduction of pain and swelling, restoration of full range of motion, increase of muscle strength and power, functional rehabilitation, and finally return to the activities. Conservative management of ACL tear is usually successful in persons who do not require movements such as pivoting and jumping. For assessing the success or failure of the treatment in ACL injuries, the three main outcome measures are ability to return to previous activity, reinjury rate, and prevalence of osteoarthritis. ${ }^{5}$

Jānu sandhi or the knee joint is a sakthimarma (marma present in lower limb) and also a vaikalyakara marma (an inury to a part which results in permanent disability to that joint). ${ }^{6}$ Janu marma is situated at the junction of $\bar{u} r u$ (thigh) and jangha (leg). Ācārya Susruta considers jānu marma as a sandhi marma. Its measurement is three anguli. Any injuries to this marma may lead to balakshaya (weakness) and khanjatha (lameness) which the subject has to suffer lifelong. ${ }^{6} \bar{A} c \bar{a} r y a$ Susruta has included the injuries to the sandhi under the umbrella term sandhimukta (injuries to joint) which is a type of bhagna. There are two types of bhagna. Kanda bhagna and sandhimukta. ${ }^{7}$ The treatment told in bhagna may be adopted in knee injuries also.

\section{CASE REPORT}

\section{- Presenting complaints}

A 28-year-old male named ' $\mathrm{X}$ ' previously healthy, complaining of pain and swelling in his right knee joint with occasional instability for the past 2 weeks.

\section{- History of presenting complaints}

The patient reported of having sustained a twisting movement to his right knee while playing football. During the time of injury, he heard a popping sound from the knee and was unable to walk due to pain, and there swelling also developed within one hour. He consulted a physician and took rest for one week. The pain and swelling used to bother him whenever he stand or walk continuously for some time or when he gives much exertion to his knee. He was then advised to take an MRI 
of right knee by the consulting physician and afterwards was advised to undergo surgery if the symptoms persist or worsens. The patient then consulted in the V.P.S.V Ayurveda college hospital for further management.

\section{- Investigations}

o X-ray- There was no radiologically detectable fractures

Table 1: INSPECTION

\begin{tabular}{|l|l|}
\hline Swelling & ++ \\
\hline Contusion / bruising & Absent \\
\hline
\end{tabular}

Table 2: PALPATION

\begin{tabular}{|l|l|}
\hline Warmth & ++ \\
\hline Tenderness & Grade 1 - lateral compartment \\
\hline
\end{tabular}

Table 3: RANGE OF MOVEMENTS

\begin{tabular}{|l|l|}
\hline Flexion & 40-degree limitation in terminal flexion \\
\hline Extension & 20-degree limitation in terminal extension \\
\hline VAS scale for pain on movements & 3 \\
\hline
\end{tabular}

Table 4: TESTS

\begin{tabular}{|l|l}
\hline Patellar tap test & Positive \\
\hline Valgus test & Negative \\
\hline Varus test & Negative \\
\hline Anterior drawer sign & Positive (slightly) \\
\hline Posterior drawer sign & Negative \\
\hline Squat test & Negative \\
\hline Lachman test & Positive
\end{tabular}

\section{TREATMENT PROTOCOL}

\section{Internal medications}

- Musthadhi marma kasayam - $60 \mathrm{ml}$ - 6am (before food)

- Punarnavadhi kasayam - $60 \mathrm{ml}$ - 6pm (before food)

- Laksha guggulu tab - 1 bid along with kasaya

- Gandha thaila - 15 drops bid (after food)

- Guggulu tiktakam ghrtam - 5ml bid (after food)

Table 5: TREATMENT PROCEDURES

\begin{tabular}{|l|l|l|}
\hline Days & Treatment done & Condition of patient \\
\hline Day 1 to 5 & Nägaradhi lepa (morning) & Swelling - reduced. \\
& and & Flexion -40-degree limitation \\
& Bandage using Murivenna (night) & Extension -20-degree limitation \\
& & Tenderness -Grade 1 - lateral compartment \\
\hline
\end{tabular}




\begin{tabular}{|c|c|c|}
\hline & & Lachman test- +ve \\
\hline Day 6 to 10 & $\begin{array}{l}\text { Dhanyamla dhāra } \\
\text { and } \\
\text { Bandage using Murivenna (night) }\end{array}$ & $\begin{array}{l}\text { Flexion -40-degree limitation } \\
\text { Extension -20-degree limitation } \\
\text { Tenderness -Grade } 1 \text { - lateral compartment } \\
\text { Lachman test- +ve }\end{array}$ \\
\hline Day 11 to 17 & $\begin{array}{l}\text { Taila dhära-Murivenna } \\
\text { and } \\
\text { Bandage using Murivenna }\end{array}$ & $\begin{array}{l}\text { Flexion -complete } \\
\text { Extension -complete with pain } \\
\text { Lachman test- +ve }\end{array}$ \\
\hline Day 18 to 24 & Patrapotali sweda & $\begin{array}{l}\text { Flexion -complete } \\
\text { Extension-complete without pain } \\
\text { Lachman test - +ve }\end{array}$ \\
\hline Day 25 to 31 & Sașitika lepa & $\begin{array}{l}\text { Flexion -complete } \\
\text { Extension } \\
\text { Lachman test - -ve } \\
\text { Anterior drawer sign - -ve }\end{array}$ \\
\hline
\end{tabular}

Table 6

\begin{tabular}{|l|l|l|l|l|}
\hline MEASUREMENTS (Girth in $\mathrm{cm})$ & BEFORE & RIGHT & LEFT & RFGER \\
\hline & RHT & LEFT \\
\hline $10 \mathrm{~cm}$ proximal to tibial tuberosity & 35 & 36 & 36 & 36 \\
\hline $20 \mathrm{~cm}$ proximal to tibial tuberosity & 39 & 41 & 40 & 41 \\
\hline
\end{tabular}

\section{DISCUSSION}

Injuries those affect the knee joint may be correlated to sandhimoksha which is one among the two types of bhagna (fractures) ${ }^{7}$ and thus bhagna cikitsā may be adopted in joint injuries. In all injuries initially an inflammatory mechanism will work in the tissue which is a protective action. Such an inflammatory mechanism if left uncontrolled without giving any management may result in a post-traumatic stiffness. Therefore, in order to get a better functional restoration the inflammatory mechanism should be allowed to remain in a very controlled manner. ${ }^{8}$ The immediate management after an injury which is mentioned in bhagna cikitsa (fracture management) is âlepa (external application of a paste) and bandhana (bandage/immobilisation). ${ }^{9}$ The alepa may help to control the inflammatory reactions and thus reduce the swelling and pain to a certain extent. Alepa may be applied till the gross swelling subsides (till the inflammation comes under control). Dur- ing this period complete rest to the joint should be advised. In this case, patient was not in an acute stage but as there was some swelling, àlepa using Nāgarādi lepa was done for the first five days. Along with älepa, Murivenna bandhana (bandage) was also done at night (12 hrs). Bandhana does the ropana of vrana (injury which the ligament has sustained), gives sandhi sthairyatha (stability to the joint) ${ }^{10}$ and also has a pressure effect on the injured area, thus controlling the occurrence of further swelling and pain to a certain extent. Along with the stability, the pharmacological effect of Murivenna used for bandhana also has a very important role. The acute anti-inflammatory effect of Murivenna has been proved clinically and experimentally. ${ }^{11}$ On removal of bandhana after the required time, parișeka/dhara (pouring of warm medicine) may be given according to the condition. Pariseka may be done as a sukōshna (slight warm) local dhara (pouring) on the affected knee. Pariseka has shramaghna quality, thus it may rejuvenate the exhausted soft tissue in the joint. Since parișeka is done with warm liquids it may 
also enhance the local circulation. The tissue metabolism may also get increased due to the pharmacological effect of the medicines used for the procedure. Thus an overall regeneration may be achieved by parisieka. As there was swelling in the knee joint, initially pariseka using dhānyamla was done. After the swelling was subsided sneha pariseka using thaila (oil) was done in view of increasing the muscle endurance / or the sustainability. ${ }^{12}$ After parișeka, the mild swelling which persisted in the knee was subsided. During this treatment period static isometric knee exercises were advised to the patient. After the subsidence of swelling, mrdu (mild) bāhya snehana and swedana were given. According to the principles of Ayurveda, snehana helps in tissue regeneration. It may especially do the nourishment of mamsa dhatu. The sneha applied on the body for a period of 600 mâtra will enter the māmsa, 700 mātra will reach medas and 800 mātra will reach asthi and majja. Since snāyu and sandhi are considered as the upadhatu of medas, a sneha applied for 700 mātra may reach the sandhi and nourish it. ${ }^{12}$. Snehana and swedana may also increase the flexibility of the knee joint and thus reduce the stiffness of the joint. ${ }^{13} \mathrm{An}$ exercise pattern done in a phased manner along with snehana and swedana was also followed by the patient which helped to maintain the muscle endurance. After snehana and swedana, the knee regained complete movements, and the muscles were improved in their tonicity. After the joint was relieved from stiffness and regained the movements, then brmhana line of management was undertaken. In any injury, after a time of immobilization and due to decreased activities, there will be disuse atrophy of the muscles which may be correlated as mamsa dhāu kshaya. ${ }^{14}$ The treatment for mamsa dhātu kshaya usually done are șastika sāli sweda ${ }^{15}$ and mamsa pinda sweda. These procedures strengthen the muscles in and around the knee joint (quadriceps, hamstrings, and gastrocnemius). In this case where mamsa dhatu kshaya was found, sastika sāli lepa was done for seven days. The instability was considerably reduced after brmhana line of management. The quadriceps attained the normal tone and texture. Along with this procedure the patient was also advised to perform kinetic knee exercises. Thus, thirty one days of treatment was done and the patient was able to walk without instability and pain and attained complete range of movements of the knee. There is a provision for watchful waiting when it comes to knee ligament and meniscal injuries. Usually the estimated non-surgical recovery timeframe for a ligament injury of knee depends on the extent of the original injury, pre-existing fitness and commitment to the rehabilitation. Complete rupture of anterior cruciate ligament with associated other ligament tears are difficult to manage conservatively unless the patient follow strict norms. In this case the patient ' $\mathrm{X}$ ' was advised strictly to restrain from activities which involves twisting movements of the knee. The patient was allowed to do all other daily activities. Movements to the knee which requires twisting forces may further damage the ligament along with meniscal tears. In such cases surgery may be required as per the advice. The patient ' $\mathrm{X}$ ' was followed up for one year and the period was uneventful.

\section{CONCLUSION}

In Ayurveda there is an existing standard treatment protocol detailed in Sușrutha Samhitha regarding the management of injuries. A proper understanding of the injury through physical examination and supported by evidence based special investigations are necessary before planning of the treatment. By a collective protocol through Ayurveda treatment an overall outcome may be achieved in terms of signs and symptoms and of post traumatic complications. Acārya Sușrutha explains that an initial conservative management should be tried in śastra sādhya vyādhi if the conditions permit and surgery is to be resorted when conservative management becomes inadequate.

\section{REFERENCES}

1. Standring. S. Gray's Anatomy: The Anatomical Basis of Clinical Practice. 29 ${ }^{\text {th }}$ ed. Edinburgh: Elsevier Churchill Livingstone; 2005.113(1471-1488).

2. Crenshaw. A.H. Campbell's operative orthopaedics. 8thed. Mosby Year book: United States of America: Mosby Year;1992.vol 3:9(1487-1732).

3. Risberg. M.A. et al. A systematic review of evidence for anterior cruciate ligament rehabilitation: how much and 
what type?. Physical Therapy in Sport. 2004 Aug 1;5(3):125-45.

4. Mahapatra P, Horriat S, Anand BS. Anterior cruciate ligament repair-past, present and future. Journal of experimental orthopaedics. 2018 Dec;5(1):1-0.

5. Brukner $P$ et al. Clinical sports medicine. New Delhi: Tata McGraw-Hill publishing company limited; 2008.3:27 (472-485).

6. Sushruta. Susrutha Samhita. Edited by Patil V.C. et al. published by Varanasi:Chaukambha publications;2018.vol-II.Sareerasthana.p 194-211.

7. Sushruta. Susrutha Samphita. Edited by Patil V.C. et al. published by Varanasi: Chaukambha publications; 2018.vol II. Nidanasthana.p 96-97.

8. Wynn TA. Cellular and molecular mechanisms of fibrosis. The Journal of Pathology: A Journal of the Pathological Society of Great Britain and Ireland. 2008 Jan; 214(2):199-210.

9. Sushruta. Susrutha Samphita. Edited by Patil V.C. et al. published by Varanasi: Chaukambha publications; 2018.vol II. Cikitsasthana.p 303-304.

10. Sushruta. Susrutha Samhita. Edited by Patil V.C. et al. published by Varanasi: Chaukambha publications; 2018.vol I.Sutrasthana.p 239.

11. Nair.V.V. et al. An experimental study to evaluate antiinflammatory activity of murivenna in wistar albino rats.IJPSR. Oct 1 2021.11(10).5091-03.

12. Sushruta, Susrutha Samhita. Edited by Patil V.C. et al. published by Varanasi: Chaukambha publications; 2018.vol II. Cikitsasthana.p 478-479.

13. Vagbhata. Ashtanga Hridaya. English translation by Srikantha Murthy. $9^{\text {th }}$ ed.Varanasi: Chaukambha Krishnadas Academy; 2017. Vol II, Cikitsasthana.

14. Appell HJ. Muscular atrophy following immobilisation. Sports medicine. $1990 \mathrm{Jul} ; 10(1): 42-58$.

15. Mangal G.et al. Exploring annalepa therapy: A review.WJPR.2020;9(8):651-657.

\section{Source of Support: Nil}

\section{Conflict of Interest: None Declared}

How to cite this URL: Sreelatha K et al: Ayurvedic Approach In The Management Of Anterior Cruciate Ligament Tear Of Knee. International Ayurvedic Medical Journal \{online\} 2021 \{cited June, 2021\} Available from: http://www.iamj.in/posts/images/upload/1287_1292.pdf 